\title{
Kemampuan Menulis Cerita Pendek melalui Media Film Siswa Kelas VII SMP Negeri 2 Palopo
}

\author{
Marlia Muklim \\ Program Studi Agribisnis \\ Hajjamarlia6@gmail.com
}

\begin{abstract}
Abstrak
Penelitian ini bertujuan untuk memperoleh gambaran yang jelas tentang kemampuan siswa kelas VII SMP Negeri 2 Palopo dalam menulis cerpen melalui media film. Dalam penelitian ini peneliti menempuh beberapa tahap penelitian, yaitu tahap pengumpulan data dan analisis data. Metode penelitian yang digunakan adalah metode deskriptif kuantitatif. Penulis mengadakan penelitian pustaka dengan teknik catat yang relevan dengan masalah yang sedang diteliti. Selanjutnya, penulis menggunakan media film untuk menilai kemampuan menulis cerpen siswa. Hasil penelitian menunjukkan siswa yang mampu memperoleh kategori kurang baik 0 (0\%) dalam interval 0-59, kemudian siswa yang mampu memperoleh kategori cukup baik 10 (33,3\%) dalam interval 60-69, dalam kategori baik yaitu 20 (66,7\%) dalam interval 70-84 dan siswa yang memperoleh kategori sangat baik 0 (0\%) dalam interval 85-100. Jadi, dapat disimpulkan bahwa kemampuan menulis cerpen melalui media film pada siswa kelas VII SMP Negeri 2 Palopo berada dalam kategori baik $(66,7 \%)$ dan siswa yang kurang mampu sebanyak 33,3\%. Jumlah siswa yang mendapat nilai $\geq 75$ hanya 56,7\% saja, sehingga menunjukkan bahwa sampel pada penelitian ini belum memenuhi kriteria yang ditetapkan, atau berada pada kategori tidak mampu.
\end{abstract}

Kata kunci: menulis cerpen, film.

\section{Pendahuluan}

Keterampilan menulis sangat penting untuk dikuasai dan dibutuhkan dalam kehidupan modern ini apalagi seorang siswa karena banyak memberikan manfaat dan kegunaan. Selain dapat mengasah pikiran dan mempertajam penalaran dalam menulis, manfaat yang lain yakni dapat meningkatkan kemampuan dalam keterampilan menulis para siswa. Tarigan (2013:4) mengemukakan bahwa kiranya tidaklah terlalu berlebihan bila kita katakan bahwa keterampilan menulis merupakan suatu ciri dari orang yang terpelajar atau bangsa yang terpelajar.

Keterampilan menulis merupakan kegiatan berbahasa yang harus diajarkan kepada siswa karena kegiatan ini merupakan penentu keberhasilan dalam pengajaran. Menulis siswa dapat lebih lebih mengenali kemampuan dan potensi diri untuk mengetahui pengetahuan siswa tentang suatu topik yang disampaikan. Pada pengajaran menulis bukan saja menghasilkan siswa-siswi yang kemampuan menulisnya baik, tetapi juga mengembangkan potensi pengajar bahasa Indonesia yang selama ini sering dikatakan kurang efektif (Suparman, 2018: 123)

Kurikulum bahasa Indonesia yang diterapkan di sekolah terdapat pembelajaran menulis, salah satunya menulis cerpen. Menulis cerpen merupakan seni/keterampilan menyajikan cerita tentang sebuah peristiwa atau kejadian pokok yang dapat dijadikan sebagai dunia alternatif pengarang. Kemampuan menulis cerpen yang dimiliki siswa tidaklah sama. Sebagian siswa mampu menulis cerpen dengan baik dan sebagian siswa yang lain masih belum mampu menulis cerpen dengan baik. Kondisi ini diperburuk dengan rendahnya minat menulis siswa. Pendapat tersebut diperkuat oleh pendapat Badudu (dalam Umar, 2015:282) bahwa keterampilan menulis siswa masih rendah 
ditandai dengan: (1) frekuensi kegiatan menulis yang dilakukan oleh siswa sangat rendah; (2) kualitas karya tulis siswa sangat buruk; (3) rendahnya antusiasme dalam mengikuti pembelajaran bahasa Indonesia pada umumnya dan pembelajaran menulis pada khususnya; dan (4) rendahnya kreativitas belajar siswa pada saat kegiatan belajar-mengajar menulis.

Berdasarkan hasil observasi terhadap siswa dan Guru Bahasa Indonesia SMP Negeri 2 Palopo, bahwa kemampuan menulis cerpen siswa kelas VII masih tergolong rendah. Rendahnya keterampilan menulis cerpen siswa tersebut terlihat dari kesulitan siswa dalam menuangkan ide atau ceritanya ke dalam bentuk tulisan. Dilihat dari sarana yang menunjang pembelajaran cerpen di sekolah sebenarnya banyak. Contohnya, seperti koran, majalah, kumpulan cerpen yang ada di perpustakaan sekolah. Siswa seharusnya bisa memanfaatkan sarana yang ada untuk mengasah kemampuan menulis cerpen, tetapi kenyataannya siswa kurang mampu menulis cerpen dengan baik, padahal sarana yang menunjang sangat memadai.

Permasalahan tersebut muncul dikarenakan proses pembelajaran bahasa Indonesia tidak efektif dan menarik. Pembelajaran menulis cerpen tidak kreatif, hal lain yang menjadi sebab tidak efektifnya pembelajaran menulis cerpen adalah siswa malas dalam menulis cerpen. Permasalahan itu timbul tidak hanya dari siswa, tetapi juga dari segi penggunaan media yang belum pernah diterapkan oleh guru sebagai penunjang berhasilnya proses pembelajaran. Oleh karena itu, agar pembelajaran keterampilan menulis cerpen kreatif peneliti menggunakan media film. Alasan menggunakan media film karena saat proses pembelajaran menulis cerpen guru belum pernah menerapkan media film tersebut, dengan adanya media film siswa lebih mengerti bagaimana menulis cerpen dengan baik.

Melalui film, siswa diharapkan terpancing untuk menumbuhkan minat, menemukan tema, serta mampu menyusun alur cerita yang bisa dituangkan ke dalam sebuah cerpen. Selain itu film merupakan suatu karya seni yang ditayangkan dalam bentuk audio visual. Dengan adanya film sebagai karya seni, siswa dapat merasa terkesan dan memiliki wawasan tentang realitas kehidupan sosial yang ada disekitarnya.

\section{Tinjauan Pustaka}

1. Pengertian menulis

Menulis ialah menurunkan atau melukiskan lambang-lambang grafik yang menggambarkan suatu bahasa yang dipahami oleh seseorang sehingga orang lain dapat membaca lambang-lambang grafik tersebut kalau mereka memahami bahasa dan gambaran grafik itu (Tarigan, 2013:22). Menurut Yunus (dalam Susanti, 2013:4), menulis dapat didefinisikan sebagai suatu kegiatan penyampaian pesan (komunikasi) dengan menggunakan bahasa tulis sebagai alat atau medianya. Selanjutnya Zainurrahman (dalam Susanti, 2013:4), mengemukakan bahwa menulis sebagai kegiatan sekaligus keterampilan yang terintegrasi bahkan menulis selalu ada dalam setiap pembelajaran, sama halnya dengan membaca.

Menurut Rosidi (dalam Mastini, 2016:25), menulis merupakan suatu keterampilan berbahasa yang dipergunakan untuk berkomunikasi secara tidak langsung, tidak secara bertatap muka dengan orang lain. Menurut Andayani (dalam Mastini, 2016:25), sebagai bentuk keterampilan berbahasa, menulis merupakan kegiatan yang bersifat mengungkapkan dengan maksud 
mengungkapkan gagasan, buah pikiran, dan perasaan kepada pihak atau orang lain dalam bentuk tulisan yang diharapkan dapat dipahami oleh pembaca dan berfungsi sebagai alat komunikasi secara tidak langsung. Oleh karena itulah, menulis merupakan suatu kegiatan produktif dan ekspresif. Hal ini sejalan dengan pendapat Nurjamal (dalam Mastini, 2016:25) bahwa menulis merupakan sebuah proses kreatif menuangkan gagasan dalam bentuk bahasa tulis untuk tujuan, misalnya, memberi tahu, meyakinkan dan menghibur.

Berdasarkan beberapa pengertian diatas disimpulkan bahwa, menulis adalah suatu kegiatan sekaligus keterampilan yang terintegrasi dalam penyampaian pesan (komunikasi) dengan melukiskan lambang-lambang grafik tentang suatu bahasa yang dapat dipahami oleh orang lain.

\section{Pengertian cerpen}

Cerita pendek merupakan bagian dari prosa, sedangkan yang termasuk prosa selain cerita pendek adalah novel dan roman. Badudu (dalam Rachman, 2017:13) mengemukakan bahwa cerpen atau cerita pendek (short story) adalah sejenis cerita yang krisis pergolakan jiwa pelakunya tidak menyebabkan perubahan nasib pelakunya, sedangkan menurut Ambari (dalam Rachman, 2017:13), cerpen atau cerita pendek adalah cerita yang hanya menceritakan salah satu peristiwa dan seluruh kehidupan yang luas tentang pelakunya. Lebih jelasnya Rusyana (dalam Rachman, 2017:13) mengemukakan bahwa cerpen adalah karangan kisahan yang isinya memaparkan terjadinya suatu peristiwa, baik peristiwa kenyataan maupun peristiwa rekaan. Berdasarkan dengan peristiwa itu dipaparkan siapa yang menjadi pelakunya, bagaimana suasana terjadinya, bagaimana jalan kejadiannya dan siapa juru ceritanya.

Definisi cerita pendek yang lebih kompleks diungkapkan oleh Jingga (dalam Mastini, 2016:26) bahwa cerita pendek merupakan cerita yang mengisahkan sebagian kecil aspek dalam kehidupan manusia yang diceritakan secara terpusat pada tokoh dan kejadian yang menjadi pokok cerita. Aminuddin (dalam Mastini, 2016:26) menjelaskan bahwa cerpen merupakan kisahan atau cerita yang diemban oleh pelaku-pelaku tertentu dengan pemeranan, latar serta tahapan dan rangkaian cerita tertentu yang bertolak dari hasil imajinasi pengarangnya sehingga menjalin suatu cerita.

Berdasarkan pengertian diatas disimpulkan bahwa cerpen adalah cerita yang hanya menceritakan salah satu peristiwa baik peristiwa kenyataan maupun peristiwa rekaan dimana krisis pergolakan jiwa pelakunya tidak menyebabkan perubahan nasib pelakunya.

\section{Menulis Cerpen}

Menulis cerpen pada hakikatnya merujuk pada kegiatan mengarang. Mengarang termasuk proses kreatif yang penulisannya dipengaruhi oleh hasil rekaan atau imajinasi pengarang. Menulis cerpen merupakan cara menulis yang paling selektif dan ekonomis. Cerita dalam cerpen sangat kompak, tidak ada bagiannya yang hanya berfungsi sebagai pelengkap. Tiap bagiannya, tiap kalimatnya, tiap katanya, tiap tanda bacanya, tidak ada bagian yang sia-sia, semuanya memberi saran yang penting untuk menggerakkan jalan cerita, atau mengungkapkan watak tokoh, atau melukiskan suasana.

Dalam menulis sebuah cerpen, seorang penulis harus memerhatikan unsur-unsur pembangun cerpen. Jalinan cerita haruslah disusun dengan menarik dan memerhatikan urutan waktu serta mengandung tokoh yang mengalami suatu peristiwa. Untuk dapat menulis cerpen dengan baik penulis 
harus memiliki pengetahuan yang cukup tentang cerpen. Penulis cerpen juga harus mampu mengedepankan pengalaman. Sesuatu yang dialami atau diketahui hendaknya direnungkan baik-baik dan dicari ujung pangkalnya sehingga dapat menimbulkan kematangan pikiran sebagai dasar dalam membuat cerita.

Menulis cerpen dapat dikatakan menuliskan "dongeng" pendek. Dongeng yang dekat dengan kehidupan nyata dan fantasi pembaca, angan-angan bahkan mungkin juga impuls atau desakan hati pembaca. Akan tetapi cerpen juga dituntut punya jiwa yang membuat cerpen itu punya daya pikat. Pengalaman dan pengetahuan penulis sangat memengaruhi karyanya. Menurut Thahar (dalam Rianto, 2017:69) bahwa fiksi (termasuk cerpen) juga berangkat dari fakta yang terhimpun dalam pengalaman batin seorang pengarang, lalu dikreasikan kembali dengan imajinasinya sehingga menjadi sesuatu yang hidup, suatu kenyataan yang baru yang kita sebut fiksi. Lebih lanjut Thahar (dalam Rianto, 2017:69) menyatakan bahwa sastra lahir (termasuk cerpen) dari sumber pengalaman sastrawan sendiri, baik pengalaman dalam bentuk lahiriah maupun pengalaman lahiriah. Pengalaman batin juga merupakan kekayaan yang tak ternilai harganya. Ia didapat dari media lain, mungkin audio atau audio visual, buku bacaan, dan tuturan orang lain.

Menurut Sudarman (dalam Rianto, 2017:69), menulis cerpen dapat dilakukan dengan langkah-langkah berikut.

1. Menentukan tema.

2. Membuat kerangka karangan.

3. Mengumpulkan referensi.

4. Menuliskan.

4. Film

Menurut Cahyono (dalam Yana, 2013:5), film merupakan film yang memiliki durasi di bawah 50 menit. Sumarno (dalam Agustina, 2015:3) menyatakan bahwa film mempunyai kemampuan kreatif untuk menciptakan suatu realitas rekaan sehingga menjadi pembanding terhadap realitas yang sebenarnya sehingga realitas imajiner tersebut dapat menawarkan rasa keindahan, renungan, atau sekadar hiburan. Maka dari itu dalam tampilannya film sudah memiliki tema dan alur cerita yang cukup jelas karena dalam pembuatan sebuah film, semua skenario sudah dipersiapkan dengan matang. Hal ini menunjukkan bahwa sebuah film memiliki kualitas dan nilai estetika yang sangat tinggi.

Media film dalam pembelajaran dapat dikategorikan kedalam media audio-visual. Sadiman (dalam Yana, 2013:6) menyatakan bahwa peranan media audio-visual dalam pembelajaran, yaitu.

a. Sebagai alat untuk memperjelas materi pembelajaran.

b. Sebagai sumber belajar bagi siswa, dimaksudkan supaya siswa mendapat pedoman dalam mengikuti proses pembelajaran.

c. Dapat memberikan pancingan dengan praktik langsung.

d. Sebagai alat untuk menarik perhatian siswa dalam pembelajaran.

e. Mengatasi sikap siswa yang pasif.

f. Mengatasi keterbatasan ruang, waktu, dan panca indra, berarti dengan media yang cukup menunjang kegiatan belajar mengajar dapat dilaksanakan sesuai yang diharapkan.

Mengingat begitu pentingnya peranan media untuk mendukung proses pembelajaran, maka film dapat digunakan sebagai media untuk meningkatkan 
kemampuan menulis cerpen siswa. Dengan menggunakan media film, kesulitan yang dihadapi siswa ketika menulis cerpen dapat dikurangi. Siswa akan lebih mudah untuk memilih dan mengembangkan tema kedalam tulisan. Hal ini dikarenakan dalam satu film memiliki banyak permasalahan yang bisa diangkat menjadi sebuah cerpen oleh siswa. Siswa juga akan lebih mudah untuk menyusun kerangka tulisan yang akan dibuat dalam bentuk cerpen (Agustina, 2015:3).

Alasan lain mengapa media film dipilih karena dalam film khususnya film terkandung sebagian besar bahkan keseluruhan unsur-unsur pembangun cerpen. Dengan menyaksikan, menonton, dan menikmati film diharapkan siswa mendapatkan sebuah rangsangan untuk menulis sebuah cerpen dengan mengangkat topik-topik yang ada dalam film. Unsur-unsur seperti tema, alur, penokohan, latar, konflik, amanat serta dialog sudah tersaji dalam film. Dengan demikian, siswa telah mampu memberikan respons yang positif dan kreatif dalam mengapresiasai sastra. Selain itu juga, film memiliki durasi dibawah 50 menit. Film dapat saja hanya berdurasi 60 detik, yang penting ide dan pemanfaatan media komunikasinya dapat berlangsung efektif. Media film yang digunakan sebagai media pembelajaran adalah film yang mengandung dan menyampaikan pesan-pesan moral kepada siswa, selain itu juga film yang dapat merangsang imajinasi siswa (Agustina, 2015:3).

\section{Metode Penelitian}

\section{Jenis Penelitian}

Jenis penelitian yang digunakan adalah penelitian deskriptif yaitu penelitian yang hanya menggambarkan atau memaparkan variabel-variabel yang diteliti tanpa menganalisa hubungan antar variabel. Data hasil penelitian disajikan dalam bentuk deskriptif agar data tersebut dapat dipahami dengan mudah (Dharma, 2011:73).

2. Desain Penelitian

Desain penelitian adalah metode yang digunakan peneliti untuk melakukan suatu penelitian yang memberikan arah terhadap jalannya penelitian (Dharma, 2011:72). Desain penelitian yang digunakan adalah desain kuantitatif. Penelitian kuantitatif memusatkan pada pengumpulan data yang berupa angkaangka untuk kemudian dianalisis dengan menggunakan alat-alat analisis kuantitatif maupun dengan perhitungan matematika.

3. Lokasi dan Waktu Penelitian

Penelitian ini dilaksanakan di Kelas VII SMP Negeri 2 Palopo. Penelitian ini dilaksanakan pada semester genap tahun 2019.

4. Definisi Operasional Variabel

Definisi operasional dimaksudkan untuk mengetahui pengertian dan kata-kata kunci yang digunakan dalam penelitian ini, yaitu sebagai berikut:

a. Menulis adalah suatu kegiatan sekaligus keterampilan yang terintegrasi dalam penyampaian pesan (komunikasi) dengan melukiskan lambanglambang grafik tentang suatu bahasa yang dapat dipahami oleh orang lain.

b. Menulis cerpen adalah proses kreatif yang penulisannya dipengaruhi oleh hasil rekaan atau imajinasi pengarang.

c. Film merupakan film-film yang memiliki durasi di bawah 50 menit. 


\section{Populasi dan Sampel}

a. Populasi

Populasi adalah keseluruhan sumber data yang diperlukan dalam suatu penelitian (Saryono, 2013:165). Populasi dalam penelitian ini adalah semua siswa Kelas VII SMP Negeri 2 Palopo sebanyak 102 orang, yang terdiri dari 30 siswa kelas VIIA, 35 siswa kelas VIIв dan 37 siswa kelas VIIc.

b. Sampel

Sampel adalah sebagian dari populasi yang akan diteliti (Hidayat, 2009:60). Apabila jumlah populasi terlalu banyak, maka jalan yang harus ditempuh adalah mengambil sebuah sampel sebagai wakil dari populasi yang sudah ditetapkan. Teknik penetapan sampel yang digunakan adalah teknik purposive sampling, atau pengambilan data secara langsung. Pengambilan sampel ini dilakukan pada saat mengadakan studi pendahuluan, mengadakan kesepakatan dengan kepala sekolah dan guru bahasa Indonesia bahwa kelas VIIA telah mewakili semua kelas untuk menguji kemampuan menulis cerpen. Sampel yang diambil dalam penelitian ini sebanyak 30 orang, yang terdiri dari 18 orang berjenis kelamin laki-laki dan 12 orang berjenis kelamin perempuan.

6. Teknik Pengumpulan Data

Teknik pengumpulan data yang perlu dalam penelitian ini dilakukan dengan berbagai cara, yakni sebagai berikut.

\section{a. Tes}

Instrumen yang digunakan dalam penelitian ini adalah instrumen tes. Bentuk instrumen tes yaitu tes menulis cerpen. Tes ini berfungsi untuk mengetahui kemampuan menulis cerpen siswa.

Peneliti memperlihatkan film kepada siswa, kemudian siswa tersebut diberikan tes untuk menulis cerita pendek.

b. Dokumentasi

Dokumentasi dalam penelitian ini berupa hasil tulisan siswa, dan dokumentasi foto kegiatan. Dokumentasi foto sebagai alat pencatatan untuk menggambarkan apa yang sedang terjadi di kelas pada waktu pembelajaran dalam rangka penelitian. Untuk menangkap suasana kelas, detail tentang peristiwa-peristiwa penting atau khusus yang terjadi atau ilustrasi dari episode tertentu, alat-alat elektronik ini dapat saja digunakan untuk membantu mendeskripsikan apa yang peneliti catat di catatan lapangan, apabila memungkinkan.

7. Teknik Analisis Data

Data yang diperoleh dalam penelitian ini adalah analisis dengan menggunakan teknik presentasi. Teknik presentasi ini digunakan untuk mengelola hasil menulis cerpen siswa. Data berupa skor mentah yang diperoleh dari hasil menulis cerpen tersebut akan diolah dengan menggunakan langkahlangkah sebagai berikut:

a. Membuat daftar skor mentah.

b. Mengelola skor yang diperoleh berdasarkan nilai menulis cerpen.

c. Transformasi skor mentah dan nilai berskala 10-100.

d. Menentukan frekuensi skor persentase yang dicapai dalam bentuk tabel.

Tolak ukur kemampuan siswa yakni jika 85\% dari jumlah siswa memperoleh nilai 75 keatas maka dianggap mampu. Tetapi, jika 85\% dari jumlah siswa memperoleh nilai di bawah 75, maka dianggap tidak mampu (Sugiyono, 2013:64). 


\section{Hasil Penelitian dan Pembahasan}

\section{Hasil Penelitian}

Berdasarkan hasil penelitian, dari 30 sampel diperoleh nilai rata-rata siswa 74,20. Nilai tertinggi yang diperoleh siswa adalah 84 , sedangkan nilai terendah yang diperoleh siswa adalah 63. Berdasarkan hasil analisis data dengan 30 siswa sampel diperoleh gambaran, yakni tidak ada siswa yang mampu memperoleh nilai 100 sebagai nilai maksimal.

Berdasarkan data tersebut, maka dapat dikemukakan bahwa dari keseluruhan sampel penelitian, perolehan skor terendah adalah 20 yang diperoleh oleh 1 siswa atau 3,3\%. Siswa sampel yang memperoleh skor 21 yaitu 5 siswa atau 16,7\%, kemudian siswa sampel yang memperoleh skor 22 yaitu sebanyak 4 siswa atau 13,3\%. Skor 23 diperoleh oleh 3 siswa atau 10\%. Siswa sampel yang memperoleh skor 24 ada 5 siswa atau 16,7\%. Skor 25 diperoleh oleh 6 siswa atau 20\% dan skor 26 diperoleh oleh 2 siswa atau 6,7\%, sedangkan pemeroleh skor tertinggi yaitu 27 diperoleh oleh 4 siswa atau 13,3\%.

Diperoleh gambaran bahwa dari 30 siswa sampel, tidak ada seorang pun siswa yang mendapat nilai tertinggi yaitu 100. Nilai tertinggi yang diperoleh oleh siswa yaitu 84 . Siswa yang mendapatkan nilai 84 berjumlah 4 siswa atau $13,3 \%$. Siswa yang mendapat nilai 81 berjumlah 2 siswa atau $6,7 \%$, siswa yang mendapat nilai 78 berjumlah 6 siswa atau 20\%, siswa yang mendapat nilai 75 berjumlah 5 siswa atau 16,7\%, siswa yang mendapat nilai 72 berjumlah 3 siswa atau $10 \%$, siswa yang mendapat nilai 69 berjumlah 4 orang atau 13,3\%, siswa yang mendapat nilai 66 berjumlah 5 siswa atau 16,7\% dan siswa yang mendapat nilai 63 berjumlah 1 orang atau 3,3\%.

Tabel Klasifikasi kemampuan menulis cerpen melalui media film

\begin{tabular}{|cccl|}
\hline No. & Nilai & Frekuensi & Persentase \\
\hline 1. & Nilai $\geq 75$ & 17 & 56,7 \\
2. & Nilai $<75$ & 13 & 43,3 \\
\hline
\end{tabular}

Berdasarkan tabel klasifikasi kemamampuan menulis cerpen melalui media film tersebut, frekuensi siswa yang memperoleh nilai $\geq 75$ yaitu 17 siswa atau 56,7 persen, frekuensi siswa yang memperoleh nilai $<75$ yaitu 13 siswa atau 43,3 persen. Jumlah siswa yang mendapat nilai $\geq 75$ (tuntas) hanya $56,7 \%$ saja, sehingga menunjukkan bahwa sampel pada penelitian ini belum memenuhi kriteria yang ditetapkan, atau berada pada kategori tidak mampu.

\section{Pembahasan}

Hasil temuan yang diperoleh dari data yang dikupas dan hasil analisis data yang telah diperoleh dalam penelitian di SMP Negeri 2 Palopo diukur berdasarkan aspek penilaian yaitu kesesuaian judul dengan isi, tema, alur, latar, tokoh dan penokohan, sudut pandang, gaya bahasa dan penggunaan bahasa. Analisis data dari kemampuan menulis cerpen melalui media film pada siswa kelas VII SMP Negeri 2 Palopo pada sampel kelas VIIA yaitu siswa yang mampu memperoleh kategori kurang baik $0(0 \%)$ dalam interval 0-59, kemudian siswa yang mampu memperoleh kategori cukup baik 10 (33,3\%) dalam interval 60-69. Dalam kategori baik yaitu 20 (66,7\%) dalam interval 70-84 dan siswa yang memperoleh kategori sangat baik $0(0 \%)$ dalam interval 85-100. Hal ini menunjukkan bahwa sebagian besar siswa $(66,7 \%)$ memiliki kemampuan yang 
baik dalam menulis cerpen melalui media film. Hasil peroleh nilai tersebut sudah mampu menggambarkan bagaimana hasil belajar siswa melalui media film mampu meningkatkan kemampuan menulis cerpen.

Penggunaan film dalam menulis cerpen siswa kelas VII SMP Negeri 2 Palopo dapat meningkatkan kemampuan menulis cerpen siswa. Hal ini disebabkan oleh beberapa faktor sebagai berikut. Pertama, pemilihan dan penggunaan film memberikan peluang kepada siswa untuk menemukan ide dan mengorganisasikan ide dengan lebih bebas sehingga aktivitas menulis menjadi aktivitas yang menyenangkan. Hal ini sejalan dengan pendapat DePorter (dalam Kurniawan, 2013:92), bahwa kondisi yang menyenangkan merupakan dasar yang baik untuk menciptakan pembelajaran yang efektif. Tanpa adanya kesenangan dalam belajar, siswa cenderung akan merasa tertekan dan hal itu berarti pembelajaran yang berkualitas akan sulit tercapai.

Pemberian contoh judul oleh guru melalui media film memudahkan siswa dalam membuat cerpen. Pemberian contoh judul yang menarik oleh guru dapat memudahkan siswa dalam menulis cerpen selain itu juga judul yang menarik dapat membuat pembaca merasa tertarik untuk membaca tulisan yang kita buat. Hal ini sejalan dengan pendapat Suhandang (dalam Kurniawan, 2013:93) yang menyatakan bahwa judul sebagai kepala karangan memiliki peran penting, terutama dalam hal menarik minat baca untuk membaca cerpen tersebut. Oleh karena itu, judul harus dibuat semenarik mungkin tanpa mengabaikan keserasiannya dengan isi. Berdasarkan hasil tes, judul cerpen siswa cenderung terdiri atas satu atau dua kata yang merupakan topik cerpen sehingga kurang menarik dan kurang variatif. Beberapa contoh judul yang diberikan oleh guru mampu memberikan inspirasi bagi siswa sehingga siswa mampu membuat judul yang lebih menarik.

Respons siswa berpengaruh terhadap perilaku siswa dalam mengikuti pembelajaran menulis cerpen dengan menggunakan film sebagai media pembelajaran. Secara klasikal, siswa memberikan respons yang sangat baik terhadap penggunaan film untuk meningkatkan kemampuan menulis cerpen siswa.

\section{Simpulan}

Sebagai akhir dalam pembahasan ini maka kesimpulan yang diperoleh dari paparan data, temuan penelitian, dan pembahasan adalah kemampuan menulis cerpen melalui media film pada siswa Kelas VII SMP Negeri 2 Palopo dikatakan belum mampu, Jumlah siswa yang mendapat nilai $\geq 75$ hanya $56,7 \%$ saja, sehingga menunjukkan bahwa sampel pada penelitian ini belum memenuhi kriteria yang ditetapkan, atau berada pada kategori tidak mampu.

\section{Daftar Pustaka}

Agustina, K.A. 2015. Penggunaan Film untuk Meningkatkan Kemampuan Menulis Cerpen Siswa Kelas IX A SMP Negeri 1 Gerokgak. Jurnal Pendidikan Bahasa dan Sastra Indonesia Undiksha, Volume 3 No. 1. Diakses, 13 Januari 2018.

Dharma, K.K. 2011. Metodologi Penelitian. Jakarta: Trans Info Media.

Hidayat, A.A.A. 2009. Metode Penelitian Keperawatan dan Teknik Analisis Data. Jakarta: Salemba Medika. 
Mastini. 2016. Peningkatan Keterampilan Menulis Cerpen melalui Metode Pembelajaran Berbasis Pengalaman dan Media Audiovisual pada Sekolah Menengah Pertama. Jurnal S2 Pendidikan Bahasa Indonesia, Volume 1 No. 1. Diakses, 10 Februari 2018.

Rachman, R.N. 2017. Peningkatan Kemampuan Menulis Cerpen melalui Penggunaan Media Audiovisual Tayangan Televisi "Cermin Kehidupan Trans 7". Jurnal Diksatrasia, Volume 1 No. 1. Diakses, 1 Februari 2018.

Rianto. 2017. Efektivitas Penggunaan Metode Sugesti-Imajinasi melalui Media Audio-Visual dalam Pembelajaran Menulis Cerpen di SMA Kelas X. Jurnal Pendidikan, Kebahasaan, dan Kesusastraan Indonesia Vol. 1, No. 1. Diakses, 1 Februari 2018.

Saryono. 2013. Metodologi Penelitian Kualitatif dan Kuantitatif. Jakarta: Nuha Medika.

Susanti, Apriliya. 2013. Penggunaan Media Gambar Berseri untuk Meningkatkan Keterampilan Menulis Narasi Siswa Kelas IV SDN Tambak Kemeraan Kecamatan Krian. Jurnal PGSD Volume 01 Nomor 02. Diakses, 1 Februari 2018.

Suparman. 2018. Keefektifan Model Picture And Picture dalam Menulis Naskah Drama Siswa Kelas VIII SMPN 2 Bua Ponrang Kabupaten Luwu. Jurnal Onoma: Pendidikan, Bahasa dan Sastra, Volume 4 Nomor 2.

Tarigan, H.G. 2013. Menulis sebagai Suatu Keterampilan Berbahasa. Bandung: Angkasa.

Umar, Seniwati. 2015. Peningkatan Keterampilan Menulis Cerpen dengan Strategi Copy the Master melalui Media Audiovisual pada Siswa Kelas IXa SMP Negeri 2 Tolitoli. Jurnal Kreatif Tadulako Online Vol. 4 No. 6. Diakses, 1 Februari 2018.

Yana, I.W.D.E.T. 2013. Penggunaan Media Film sebagai Upaya Meningkatkan Keterampilan Menulis Naskah Drama Siswa di Kelas XI IPA 2 SMA Negeri 1 Payangan. Jurnal Universitas Mahasaraswati Gianyar. Diakses, 19 Februari 2018. 